\title{
Literatura kobiet w latach 1918-1939 z perspektywy feministycznej. Rekonesans
}

\begin{abstract}
Wstęp
Celem moim jest prezentacja najważniejszych wyników badań nad twórczością literacką i paraliteracką kobiet w dwudziestoleciu międzywojennym, uwzględniających perspektywę genderową, a zatem czyniących punktem odniesienia kategorię $\mathrm{płci}^{1}$. Za przedmiot badań obrałam hasła słownikowe omawiające biografię i twórczość pisarek polskich 1. połowy XX wieku oraz świadectwa odbioru tzw. literatury kobiecej, przede wszystkim recenzje rozsiane w prasie literackiej i społeczno-kulturalnej międzywojnia. Interesował mnie bowiem sposób, w jaki konstruowane są biografie intymne i artystyczne kobiet, w jaki sposób krytyka literacka wypowiada się na temat twórczości kobiet, czy literatura kobieca powstająca w latach 1918-1939 świadoma była własnych wielorakich uwarunkowań oraz czy literatura ta diagnozowała społeczną sytuację kobiet $\mathrm{w}$ pierwszych dekadach $\mathrm{XX}$ wieku².
\end{abstract}

\section{W porządku biografii}

Biogramy polskich pisarek, zamieszczane w dawniejszych i we współczesnych encyklopediach i słownikach ${ }^{3}$, skonstruowane są w ten

1 Ponieważ język polski dysponuje jednym wyrazem ,płeć”, polskie studia nad społeczną tożsamością płci używają angielskich słów dla rozróżnienia płci biologicznej (sex) i płci kulturowej (gender).

2 Najbardziej znaną i konsekwentną przedstawicielką krytyki feministycznej w Polsce jest prof. dr hab. Inga Iwasiów, autorka takich książek, jak: Kresy w twórczości Włodzimierza Odojewskiego. Próba feministyczna, Szczecin 1994; Opowieść i milczenie. O prozie Leopolda Tyrmanda, Szczecin 2000; Rewindykacje. Kobieta czytajaca dzisiaj, Kraków 2002; Gender dla średnio zaawansowanych. Wykłady szczecińskie, Warszawa 2004. 
sposób, że nie uwzględniają dat i faktów bardzo ważnych w ich życiu, np. relacji rodzinnych i małżeńskich, macierzyństwa lub bezdzietności, poważnych chorób. Wynika z tego, że redaktorzy biogramów stosowali i nadal stosują hierarchie męskie do opisu rzeczywistości kobiecej ${ }^{4}$. Na pierwszy rzut oka, bohaterki tak napisanych biogramów wydają się nie posiadać rodziny, choć w rzeczywistości ogromna część z nich wyszła za mąż i urodziła dzieci, co niewątpliwie miało wpływ na ich postrzeganie samych siebie jako kobiety i jako artystki, na ich hierarchię wartości i tryb pracy. Nie można przy tym nie zauważyć, że pisarki uważane powszechnie w XX w. za wybitne, np. Maria Dą̧browska, Maria Pawlikowska-Jasnorzewska, Hanna Malewska, Zofia Nałkowska, zrezygnowały z macierzyństwa.

Jeśli w biogramach pojawiają się informacje dotyczące relacji rodzinnych pisarek, w przytłaczającej większości dotyczą one relacji z mężczyznami twórczymi - ojcami, synami, braćmi, mężami, przyjaciółmi - co sugeruje, że ten typ relacji jest w życiu kobiet najistotniejszy. Przykładowo: w większości encyklopedii Maria Czapska jest siostrą Józefa, Maria Morstin-Górska - siostrą Ludwika Hieronima Morstina, Helena Boguszewska - żoną Jerzego Kornackiego, Maria Dąbrowska - partnerką życiową Stanisława Stempowskiego, Irena Krzywicka - synową Ludwika Krzywickiego i przyjaciółką Tadeusza Żeleńskiego, Maria Kuncewiczowa - żoną Piotra itd. Prawidłowość ta nie działa w odwrotną stronę, tzn. nazwiska kobiet, z którymi związany był lub jest mężczyzna z reguły nie pojawiają się w jego biogramie, co w zestawieniu z biogramami kobiet ujawnia również milczące założenie zależności intelektualnej kobiety twórczej od twórczego mężczyzny. O ile sytuacja powyższa wydaje się zrozumiała w wypadku córki lub wnuczki znanego literata, np. Anieli Gruszeckiej, Zofii Nałkowskiej, Zofii Kozarynowej (wnuczki Tomasza Teodora Jeża), albo znanego malarza, np. Marii Pawlikowskiej-Jasnorzewskiej i Magdaleny Samozwaniec z rodu Kossaków czy Marii Gerson-Dąbrowskiej, o tyle trudno sobie wyobrazić, że w parach małżeństw pisarskich wpływ wywiera wyłącznie strona męska.

3 Większość współczesnych słowników i encyklopedii literatury polskiej bazuje na informacjach zgromadzonych w Polskim Słowniku Biograficznym oraz tzw. Nowym Korbucie.

4 Opis tego typu praktyk (w życiu codziennym oraz w różnych dziedzinach sztuki i nauki), mających źródło w charakterystycznym dla kultury Zachodu andronormatywizmie lub androcentryzmie, przyniosło wielotomowe wydawnictwo Kobieta $i$..., t. 1-8, pod red. A. Żarnowskiej, A. Szwarca, Warszawa 1990-2004. 
Co najważniejsze jednak, biogramy autorek należących do dwudziestolecia międzywojennego konstruowane przez redaktorów z 2. poł. $\mathrm{XX}$ w. nie mają wiele wspólnego z postrzeganiem tych pisarek przez publiczność, do której się one pierwotnie zwracały, czyli przez czytelników międzywojennych. Maria Czapska, Helena Boguszewska, Maria Kuncewiczowa, Maria Dąbrowska i in. funkcjonowały wówczas w powszechnej świadomości jako autorki niezależne od mężczyzn zarówno na płaszczyźnie osobistej, jak i artystycznej. Jedyny rodzaj koneksji i wpływów wskazywanych w ich twórczości przez ówczesną krytykę to inspiracje, jakie czerpały polskie pisarki z twórczości autorek obcych, np. Selmy Lagerlöf, Sigrid Undset, Colette.

Do rzadkości należą informacje o przyjaźniach intelektualnych i emocjonalnych dwóch kobiet piszących, np. Marii Dąbrowskiej i Anny Kamieńskiej, fascynacjach literackich, np. Ireny Krzywickiej twórczością Marii Pawlikowskiej-Jasnorzewskiej, przejęciu schedy ideowej, np. idei pedagogicznych Stefanii Sempołowskiej przez jej uczennicę Halinę Górską. Na usprawiedliwienie redaktorów haseł słownikowych trzeba jednak dodać, że istotnie kobiety twórcze rzadko utrzymywały bliskie kontakty nie tylko z innymi kobietami twórczymi, lecz w ogóle z innymi kobietami, co wynikło - jak potwierdzają dzienniki, wspomnienia i listy z odruchu rywalizacji i braku czasu, które raczej bliskości nie sprzyjaja. Te same źródła potwierdzają istnienie bliskich - zwykle lekceważonych przez biografów - relacji pisarek z matkami, siostrami, córkami, a także z domownikami funkcjonującymi na szczególnych zasadach, czyli ze służącymi.

Pisarki okresu międzywojennego uważane są za przedstawicielki warstwy inteligenckiej ${ }^{5}$. Za tą pozornie oczywistą konstatacją dotyczącą przynależności klasowej kryje się jedno z najważniejszych zjawisk, które w latach 1918-1939 przekształciły strukturę społeczeństwa polskiego i umożliwiły awans życiowy kobietom oraz przedstawicielom warstw pozbawionych dotąd znaczenia politycznego. To zjawisko radykalnej zmiany znaczenia inteligencji - jednej z trzech warstw średnich (obok pracowników umysłowych i drobnomieszczaństwa), sytuujących się między zamożnym mieszczaństwem i ziemiaństwem a proletariatem. W latach międzywojennych zaczęto zaliczać do niej wszelkiego rodzaju specjali-

5 Por. J. Żarnowski, Spoleczeństwo Drugiej Rzeczpospolitej 1918-1939, Warszawa 1973. 
stów, począwszy od przedstawicieli wolnych zawodów po inżynierów, ponieważ cechą decydującą o „inteligenckości” stał się dyplom szkoły wyższej. Inteligencja była wewnętrznie zróżnicowana - jej warstwy wyższe („dyplomowane”) zbliżały się do bogatego ziemiaństwa i mieszczaństwa, podczas gdy rzesze pracowników umysłowych z miernym wykształceniem, niskimi dochodami i brakiem możliwości awansu bliższe były drobnomieszczaństwu. Szczególną grupą było środowisko intelektualistów (artystów, publicystów, krytyków, literatów i naukowców, szczególnie humanistów), skromne liczebnie, lecz posiadające świadomość własnej odrębności, wewnętrznej więzi oraz misji społecznej. W dwudziestoleciu międzywojennym model kultury inteligenckiej utożsamiono z modelem kultury narodowej, z jej - nazwijmy to umownie - wersją oficjalną.

Osobną grupę wewnątrz inteligencji stanowili nauczyciele, którzy ze względu na uposażenie i masowość zawodu bliżsi byli niższej warstwie pracowników umysłowych, mimo że funkcja społeczna łączyła ich z inteligencją o wyższych kwalifikacjach. W dwudziestoleciu wystapiło po raz pierwszy na szeroką skalę charakterystyczne zjawisko feminizacji zawodu nauczycielskiego na najniższym szczeblu kształcenia, przygotowane jeszcze przez wiek XIX, w którym kobiety najszybciej uzyskały dostęp do zawodu odpowiadającego ich „,naturalnym” skłonnościom i roli społecznej. Kiedy Sejm Nauczycielski w 1919 r. opowiedział się za jednolitą i bezpłatną szkołą powszechna, wprowadzeniem 7-letniego obowiązku szkolnego oraz powiązaniem ze sobą wszystkich szczebli szkolnictwa (co miało otwierać drogę do wykształcenia wyższego bez względu na status majątkowy, pochodzenie i typ ukończonej szkoły średniej), przypieczętował także los nauczycielek.

Organizacja szkolnictwa powszechnego wymagała bowiem natychmiastowego zatrudnienia dużej liczby nauczycieli, co w praktyce oznaczało, że mężczyźni nauczali przedmiotów ścisłych, języków nowożytnych i klasycznych w starszych klasach szkół powszechnych, ponieważ posiadali dyplomy szkół wyższych, a przynajmniej maturę, natomiast kobiety nauczały w klasach niższych, ponieważ większość z nich zdobyła kwalifikacje zawodowe na przedwojennych kursach i szkoleniach. Kobiety przeważały liczebnie nie tylko na poziomie wczesnoszkolnym, lecz również w oświacie pozaszkolnej, np. w świetlicach, bibliotekach, ochronkach, gdzie prowadziły kursy i odczyty. Wykonywały więc pozytywistyczną pracę u podstaw, upowszechniając kanon kultury polskiej i literatury wysokiej w tych warstwach, które dotąd pozostawały na marginesie zainteresowań elit politycznych. 
Jeśli czytać biogramy pisarek międzywojennych w kontekście przemian wewnątrz warstwy inteligenckiej, okazuje się, że ogromna część z nich pracowała w szkołach, świetlicach, ośrodkach ludowych, ochronkach, bibliotekach, czyli pracowała z dziećmi i młodzieżą. I nie tylko ze względu na niepełne wykształcenie, lecz ze względu na pochodzenie społeczne, ponieważ nauczycielki, które opuściły środowisko proletariackie lub drobnomieszczańskie, podzielały inteligenckie przekonanie o odpowiedzialności tej warstwy za resztę narodu, a ponadto czuły się w obowiązku spłacić dług wobec środowisk, które opuściły dzięki zdobytemu wykształceniu. Wielu z nich bliskie były ideały socjalizmu. Niektóre były zdeklarowanymi komunistkami, np. Helena Bobińska, Stefania Kierczyńska czy Wanda Wasilewska, działalność oświatową traktowały więc dodatkowo jako akcję uświadamiająca, co utrudniało im, np. Janinie Broniewskiej i Wandzie Wasilewskiej, znalezienie i utrzymanie stałej pracy.

Wykształcenie uniwersyteckie zdobyła większość pisarek polskich, których młodość i dojrzałość przypadły na lata międzywojenne, bez względu na to, czy pochodziły z rodzin ziemiańskich, jak np. Maria Czapska czy Maria Morstin-Górska, artystycznych, jak np. Aniela Gruszecka, Wanda Melcer, siostry Kossak, żydowskich, jak np. Zuzanna Ginczanka, Gustawa Jarecka, Lucyna Krzemieniecka, Irena Krzywicka. Większość pisarek wybrała filologię polską. Przewagę absolwentek kierunków humanistycznych, filologii polskiej i obcych, filozofii, socjologii, pedagogiki, historii, można wytłumaczyć na kilka sposobów, m.in. trwałością przekonań na temat „naturalnych” predyspozycji kobiet do opiekowania się innymi ludźmi, do wychowania i nauczania dzieci i młodzieży, trwałością postszlacheckiego modelu edukacji salonowej, która kładła nacisk na języki obce, najwyższym prawdopodobieństwem znalezienia pracy w zawodzie nauczycielki, pisarki, publicystki, tłumaczki, urzędniczki. $\mathrm{W}$ istocie, pisarki w dwudziestoleciu międzywojennym zdominowały trzy dziedziny, w których nakładały się na siebie społeczne przekonania na temat natury kobiecej, wykształcenie humanistyczne, a zwłaszcza filologiczne oraz zainteresowania indywidualne, a mianowicie: nauczycielstwo na najniższym szczeblu kształcenia ściśle powiązane z literaturą dla dzieci i młodzieży, publicystykę ściśle powiązaną z czasopiśmiennictwem dla kobiet, translatologię ściśle powiązaną z literaturą popularną.

Literatura dziecięca, pisma kobiece i tłumaczenia stanowiły nisze na rynku wydawniczym, szybko opanowane przez kobiety, ponieważ kojarzone były z cechami i zdolnościami tradycyjnie przypisywanymi kobietom: 
emocjonalnością, empatią, cierpliwością, odtwórczością, drobiazgowością itd. Cechy i zdolności tradycyjnie przypisywane mężczyznom: racjonalizm, ambicja, twórczość, oryginalność, nowatorstwo, syntetyczność itd. kierowały ich w stronę literatury wysokiej, literatury dla dorosłych, publicystyki o tematyce „poważnej” (polityka, ekonomia, sztuka). Jeśli już mężczyzna zapuszczał się w rejony literatury dziecięcej, dawał popis wirtuozerii formalnej, jak np. Julian Tuwim; jeśli już wypowiadał się w tzw. kwestii kobiecej, przyjmował pozę obrońcy i rzecznika kobiet, jak np. Tadeusz Żeleński; jeśli już tłumaczył, wybierał arcydzieła i rywalizował z oryginałem, jak np. Tadeusz Żeleński, Julian Tuwim, Józef Wittlin.

Można porównać te trzy dziedziny - literaturę dziecięcą i młodzieżową, pisma kobiece i przekłady - do terytoriów, na których kobiety „zamieszkały” i pracowały z poczuciem misji rozumianej na sposób pozytywistyczny. Wykonywały swoją pracę systematycznie, grupowo, anonimowo, ponieważ nastawione były na cel oraz na innych ludzi, czyli na kształtowanie emocjonalne, intelektualne i etyczne przyszłych obywateli polskich, poprawienie losu kobiet w społeczeństwie, przyswojenie kulturze narodowej osiagnięć artystycznych innych narodów. Mężczyźni przybywali na te tereny „gościnnie”, raczej w celu przeżycia przygody, zdobycia nowych doświadczeń i sprawdzenia umiejętności niż po to, by po prostu pracować; nastawieni na siebie, głośno podkreślali swoją na tych terenach obecność.

Liczba czasopism adresowanych do kobiet wzrastała systematycznie, np. w połowie lat $30 . \mathrm{XX}$ w. istniało ich ok. $30^{6}$. Dynamiczny rozwój tego działu czasopiśmiennictwa odzwierciedlał ogólne tendencje charakterystyczne dla kultury masowej XX w., a przede wszystkim - rozwój prasy traktowanej jako podstawowe medium informacji i rozrywki, który odpowiadał wzrastającej alfabetyzacji społeczeństwa i różnicowaniu się gustów czytelniczych. Przykładem na poszerzanie się i różnicowanie kręgu czytelniczek pism kobiecych może być rozwój wydawnictwa „Bluszcz”, które początkowo wydawało jeden z najstarszych tygodników dla kobiet pod tą samą nazwą, by z każdym niemal rokiem poszerzać ofertę o nowe tytuły, np. „Kobieta w Świecie i w Domu”, „,Dziecko i Matka”, „Życie Kobiece”, „Kultura Ciała”, „Ja to zrobię”, „Życie Praktyczne”, „Praktyczna

${ }^{6}$ Por. Z. Zaleska, Czasopisma kobiece w Polsce: materiaty do historii czasopism 1818-1937, Warszawa 1938; A. Paczkowski, Prasa polska w latach 1918-1939, Warszawa 1980. 
Pani - Dobra Obywatelka”. Mimo, że redagowany przez Stefanię Podhorską-Okołów „Bluszcz” kontynuował swoją XIX-wieczną linię, czyli zwracał się do kobiet o bardziej tradycyjnych poglądach, jego tytuły satelickie kupowały różne czytelniczki, zainteresowane okresowo, np. pielęgnacją niemowląt czy zdrowym trybem życia.

Czytelniczki bardziej zainteresowane życiem publicznym kraju kupowały redagowany przez Emilię Grochowską tygodnik „Kobieta Współczesna", skupiający się głównie na sytuacji prawnej kobiet pracujących, przygotowaniem kobiet do udziału w życiu publicznym, prokreacją, np. kwestią karalności aborcji. Istniały także magazyny poświęcone modzie, wśród których wyróżniał się dwutygodnik „Świat Kobiecy”, redagowany przez Janinę Łada-Walicką, oraz krótko istniejący miesięcznik „Pani”, redagowany przez Jana Żyznowskiego. Wymienione wyżej tytuły należały do grupy czasopism elitarnych, co oznacza, że wychodziły w ok. 10 tys. egzemplarzy, zwracały się do czytelniczek wykształconych i zainteresowanych zmieniającą się sytuacją kobiety w rodzinie i społeczeństwie, publikowały materiały literackie na wysokim poziomie, m.in. utwory prozatorskie Marii Dąbrowskiej, Zofii Nałkowskiej, Marii Kuncewiczowej, liryki Kazimiery Iłłakowiczówny, Marii Pawlikowskiej-Jasnorzewskiej i in.

Model kobiety, jaki propagowały międzywojenne czasopisma kobiece, odbiegał radykalnie od modelu kobiety sprzed I wojny światowej, ponieważ zakładał łączenie pracy zawodowej z obowiązkami domowymi. Kobieta nowoczesna/aktywna, która była bohaterką pozytywną prasy kobiecej, miała wzorowo wypełniać obowiązki domowe i rodzinne, inaczej mówiąc - praca zawodowa nie mogła przeszkadzać jej w wypełnianiu roli pani domu, żony i matki. Priorytetami nadal pozostały dom i rodzina, a jakiekolwiek niedociagnnięcie w tej sferze podważało sens podjęcia przez kobietę pracy zawodowej i dyskwalifikowało jej wartość, potwierdzało bowiem argumenty przeciwników kobiecej aktywności zawodowej, postrzegających pracę kobiet jako zagrożenie dla integralności rodziny. Nowy wzór osobowy przewidywał aktywność kobiety na płaszczyźnie rodzinnej, zawodowej i społecznej, co prowadzi do wniosku, że kobiety musiały okupić się społeczeństwu zwiększoną aktywnością na jego rzecz oraz przekonać je bardziej do tego, że nic nie straci, niż do tego, że wiele zyska. Dlatego w międzywojennym ,dyskursie pracy zawodowej kobiet” zwolenniczki/cy pracy zawodowej kobiet podkreślali społeczną użyteczność tradycyjnych cnót kobiecych poza sferą rodzinną, a dopiero w następnej kolejności - indywidualną satysfakcję kobiety z wykonywanej pracy oraz jej aspekt finansowy. 
Kobiety przekładały wszystko, począwszy od ckliwych romansów i powieści detektywistycznych poprzez literaturę dziecięcą i młodzieżową na arcydziełach literatury światowej kończąc ${ }^{7}$. Nie znaczy to, że thumacze płci męskiej należeli do rzadkości, wprost przeciwnie, lecz uprawiali tę działalność wedle innego modelu niż tłumacze płci żeńskiej. Mężczyzna tłumacz rzadko traktował dziedzinę przekładu jako podstawową lub jedyną dziedzinę swojej działalności pisarskiej, zazwyczaj stanowiła ona uzupełnienie lub przedłużenie jego twórczości oryginalnej, fascynacji artystycznych i poszukiwań intelektualnych. Istotną sprawą było także niskie uposażenie tłumaczy w dwudziestoleciu. Tłumacz płci żeńskiej to raczej rzemieślnik, który wykonywał swoją pracę szybko i sprawnie. Dla większości kobiet praca przekładowa była jedyną lub główną dziedziną aktywności pisarskiej, dlatego zazwyczaj wiązały się one z dużymi wydawnictwami, pracowały na zlecenie i dla zarobku Efektem ich pracy znacznie częściej był przedmiot użytkowy, książka traktowana jako źródło wiedzy lub rozrywki, niż dzieło sztuki, ponieważ przyswajały polszczyźnie głównie gatunki „deficytowe”: powieści kryminalne, przygodowe, sensacyjne, podróżnicze i miłosne, inaczej mówiąc - dobrze napisane powieści klasy $\mathrm{B}$, dla czytelników dorosłych i niedorosłych.

Brak polskich odpowiedników Edgara Wallace'a, Agathy Christie, Williama Somerseta Maughama, Williama Babingtona Maxwella, Elinor Glyn - autorów niezwykle popularnych w okresie międzywojennym w całej Europie, obok pozostałości salonowego wychowania kobiet kładącego nacisk na naukę języków, stał się w latach 1918-1939 szansą na znalezienie pracy i zaistnienie $\mathrm{w}$ literaturze dla kobiet $\mathrm{z}$ różnych pokoleń. Wymienione wyżej nazwiska pisarzy nieprzypadkowo wskazują na literaturę angielską i prozę mieszczącą się w ramach szeroko rozumianej konwencji realistycznej, ponieważ tłumaczki polskie upodobały sobie powieść i język angielski. Kobiety stanowiły ponad 70\% wszystkich tłumaczy z języka angielskiego, co można wyjaśnić rodzącą się dopiero popularnością tego języka w Polsce: kobietom nie pozostało nic innego, jak zdobyć nowe terytorium szturmem, ponieważ monopol na tłumaczenia z innych języków, przede wszystkim francuskiego, niemieckiego i rosyjskiego, na mocy tradycji posiadali mężczyźni. Mężczyźni posiadali również monopol na tłumaczenia poezji oraz prozy modernistycznej, wy-

${ }^{7}$ Por. S. Żółkiewski, Kultura literacka (1918-1932), Wrocław 1973; E. Kurowska, Recepcja literatury angielskiej w Polsce (1932-1939), Wrocław 1987. 
magające opanowania warsztatu poetyckiego w języku ojczystym, głębszej znajomości struktury języka obcego oraz kontekstu filozoficznego epoki. Taką wiedzę i umiejętności zdobywało w Polsce niepodległej dopiero pierwsze pokolenie absolwentek filologii polskiej i obcej, które weszło do literatury pod koniec lat 30 . i po II wojnie światowej.

$\mathrm{W}$ tej sytuacji tradycyjne przekonania na temat cech umysłowości kobiety, które dwudziestolecie odziedziczyło po stuleciu poprzednim, ówczesnym obserwatorom życia literackiego wydawały się słuszne. Kobiety tłumaczki pełniły bowiem przede wszystkim funkcję pośredniczącą, czyli przyswajały kulturze polskiej dokonania literatur obcych, prezentowały cudze idee, traktowały język jako narzędzia komunikacji, a nie jako przedmiot obróbki twórczej. Krytyka w tym samym stopniu deprecjonowała, co i utwierdzała taki model kobiecej pracy przekładowej, ponieważ ze wzmianek rozsianych na łamach prasy międzywojennej wynika, że zdecydowanie częściej wymóg wierności i staranności stawiany był tłumaczkom, wymóg artyzmu - tłumaczom.

Odkrycia poczynione u progu XX w. na gruncie nowych nurtów psychoanalizy, pedagogiki i filozofii zmieniły również oblicze literatury dla dzieci i młodzieży ${ }^{8}$. Dzieciństwo zaczęto postrzegać jako odrębną i ważną dla dalszego życia osobistego fazę, charakteryzującą się ogromną wrażliwością na świat zewnętrzny, przewagą emocji, intuicji, wyobraźni i zabawy nad rozumem, wiedzą i poczuciem obowiązku. Twórcy literatury dla dzieci i młodzieży, dzięki przyjęciu perspektywy dziecka, zaczęli traktować młodocianych czytelników jako podmiot, nie - przedmiot zabiegów dydaktycznych. Nowe tendencje dotarły do Polski głównie dzięki środowisku działaczy oświatowych, nauczycieli, pedagogów i socjologów wykształconych przed I wojną światową albo na uniwersytetach zagranicznych, albo na polskim Uniwersytecie Latającym. Duża część tych nauczycieli była związana z PPS lub sympatyzowała z socjalizmem, wzięła udział w tworzeniu struktur państwowych po 1918 r. i wpłynęła na sformułowanie zapisów o powszechnej edukacji. To pokolenie napisało nowe programy nauczania, spisy lektur i podręczniki, założyło najważniejsze czasopisma dla dzieci i młodzieży, stworzyło pierwszą falę nowoczesnej literatury dziecięcej i młodzieżowej, w której Jachowiczowską makabrę zastapił optymistyczny, pogodny stosunek do świata i ludzi.

8 Por. J. Z. Białek, Literatura dla dzieci i młodzieży w latach 1918-1939. Zarys monograficzny. Materiaty, wyd. II zmienione, Warszawa 1987. 
Większość pism branżowych, wśród których największą popularnością cieszyły się „Płomyk” „Płomyczek” i „Mały Płomyczek” (wydawane na potrzeby szkoły powszechnej, a zatem najbardziej demokratyczne w programie), „Moje Pisemko” (skierowane do średniego mieszczaństwa i inteligencji), „W słońcu” i „Słonko”, redagowały kobiety, m.in. Maria Buyno-Arctowa, Stefania Sempołowska, Janina Mortkowiczowa, Janina Porazińska. Różnorodność form (czasopisma i książki, edycje ekskluzywne i zeszytowe, poezja, proza, sztuki teatralne i audycje radiowe, nagrania płytowe), jakie w ramach literatury dla dzieci i młodzieży uprawiały w dwudziestoleciu kobiety pozwala uznać ją obok przekładu i reportażu za najważniejsze „boczne drzwi”, którymi kobiety wchodziły masowo do literatury ,,poważnej”/,,wysokiej” i uczestniczyły w tworzeniu kultury narodowej. Do najpopularniejszych autorek literatury dziecięcej i młodzieżowej należały m.in. Maria Czeska-Mączyńska, Janina Broniewska, Maria Buyno-Arctowa, Maria Dynowska, Maria Gerson-Dąbrowska, Joanna Gillowa, Amelia Hertzówna, Kazimiera Iłłakowiczówna, Hanna Januszewska, Jadwiga Korczakowska, Zofia Kossak-Szczucka, Maria Kownacka, Lucyna Krzemieniecka, Michalina Mossowiczowa, Janina Porazińska, Zofia Rogoszówna, Zuzanna Rabska, Waleria Szalay-Groele, Ewa Szelburg-Zarembina.

Dominacja kobiet przełożyła się, np. w prozie na tematykę utworów i kreację bohaterów w ten sposób, że umieszczały one akcję w naturalnym dla dziecka środowisku rodzinny lub grupy rówieśniczej, kładły nacisk na wartości tradycyjnie uważane za kobiece, bez względu na płeć głównych postaci. Relacje rodzinne, solidarność i współpraca w grupie, odpowiedzialność za najbliższych, bezinteresowna pomoc, wspólna zabawa i nauka, o których pisały kobiety, odbiegały od rozwiązań stosowanych w powieściach Kornela Makuszyńskiego (dziewczynka dorasta do bycia „prawdziwą” kobietka) i ,traktatach” Janusza Korczaka (chłopiec konfrontuje się ze „złym” światem). Z kolei w liryce kobiet trudno znaleźć ten model poezji dla dzieci, który uprawiali Jan Brzechwa i Julian Tuwim, zakorzeniony w tradycji zachodniej, a szczególnie w tradycji angielskiej nursery rhymes i rodzimego pure nonsensu. Można przypuszczać, że ważną rolę odgrywał tu odmienny stosunek do poezji i języka polskiego, który, np. dla twórców pochodzenia żydowskiego, szczególnie dla Juliana Tuwima, był przede wszystkim ojczyzną - przedmiotem miłości i przedmiotem zabawy, a nie tylko narzędziem komunikacji. Wiersze dla dzieci to drugi biegun eksperymentu poetyckiego uprawianego przez autora Wiosny w poezji ,poważnej”, a do eksperymentu było jeszcze polskim poetkom międzywojennym daleko. 
W latach 30. w literaturze dla dzieci i młodzieży ujawniły się te same tendencje, co w literaturze dla dorosłych. Czołowe przedstawicielki nurtu społecznego w literaturze dziecięcej - Janina Broniewska, Helena Boguszewska, Halina Górska, Ewa Szelburg-Zarembina, Elżbieta Szemplińska, nie uciekały od problemów współczesności i pisały książki o życiu dzieci pochodzących z różnych warstw społecznych. Bohaterowie ich utworów to dzieci bezdomne, wykolejone przez nędzę, niepełnosprawne, mieszkańcy robotniczych kamienic, bywalcy świetlic, gazeciarze; to dzieci znane pisarkom z kontaktów osobistych lub obserwacji prowadzonych w szkołach, świetlicach, ośrodkach opieki. Najlepsze książki w tym nurcie - autorstwa Heleny Boguszewskiej i Haliny Górskiej - łączyły problematykę społeczną z problematyką kształtowania charakteru i kreowały wzory osobowe bohaterów aktywnych, odważnych, zdolnych do szlachetnych uczuć i działania na rzecz innych ludzi. Utwory autorek komunistycznych, np. Wandy Wasilewskiej czy Heleny Bobińskiej, propagowały ponadto szacunek dla pracy i wiarę w ludzką solidarność. Spośród wszystkich odmian literatury młodzieżowej okresu międzywojennego gatunkiem najbardziej schematycznym i opornym na zmiany okazała się powieść dla dziewcząt. Sentymentalno-ckliwe schematy udało się przekroczyć jedynie Marii Kann oraz Halinie Auderskiej, których bohaterki odważnie rozmawiały o sensie życia, czerpały zadowolenie z nauki, sportu i dziewczęcych przyjaźni.

\section{W porządku literatury}

Termin „literatura kobieca” zakłada, że - po pierwsze - istnieje opozycja binarna między literaturą kobiecą i literaturą męską, oraz że - po drugie - różnica między tymi dwoma rodzajami twórczości wynika z różnicy płci autora. Po raz pierwszy podział na twórczość męską i kobieca, literaturę męską i kobiecą pojawił się w XIX w., kiedy na skalę dotąd nie spotykaną kobiety weszły do literatury9. Termin „literatura kobieca” został więc stworzony przez mężczyzn, krytyków i twórców, którzy postrzegali masową obecność kobiet w życiu literackim jako naruszenie tradycyjnego męskiego terytorium, a utwory pisane przez kobiety postrzegali jako od-

9 Dane do analizy produkcji poetyckiej, prozatorskiej i dramatycznej kobiet w latach 30. XX wieku zaczerpnęłam z „Rocznika Literackiego” (za lata 1932-1938), Warszawa 1933-1939. 
stępstwo od obowiązujących reguł pisania. Pisarki XIX w. oceniane były wedle stopnia przyswojenia reguł rządzących pisarstwem męskim, np. te, którym udało się przyswoić reguły, uważano za lepsze od tych, które przystosowały się gorzej. W latach 1918-1939 termin ,literatura kobieca” został doprecyzowany, uzupełniony o nowe aspekty, dostrzeżone przez krytyków literatury w utworach takich pisarek, jak np. Maria Dąbrowska, Pola Gojawiczyńska, Aniela Gruszecka, Irena Krzywicka, Wanda Melcer, Zofia Nałkowska. Wypowiedzi najbardziej znanych krytyków literatury i publicystów tego okresu, m.in. Ignacego Fika, Pawła Hulki-Laskowskiego, Karola Irzykowskiego, Stefana Kołaczkowskiego, Ludwika Hieronima Morstina, Włodzimierza Pietrzaka, Leona Piwińskiego, publikowane na łamach prasy społeczno-kulturalnej i literackiej, zawierają obszerny rejestr cech "kobiecego" utworu literackiego ${ }^{10}$.

Rejestr cech to w zasadzie rejestr zarzutów, obejmujący preferowane tematy, konwencje i gatunki literackie, typy bohaterów, sposób kreacji świata przedstawionego, styl. Wśród ulubionych tematów literatury kobiecej umieszczano miłość (różne konfiguracje relacji damsko-męskich), rodzinę (relacje między małżonkami, relacje między rodzicami i dziećmi, macierzyństwo), ciało kobiece (erotyka, fizjologia, np. menstruacja, ciąża, poród), bliski kontakt z przyrodą, kontakty między kobietami. Do preferowanych konwencji literackich zaliczano realizm, naturalizm, weryzm, psychologizm, czasami ekspresjonizm, a do gatunków - powieść, opowiadanie, reportaż, erotyk. Grupa ulubionych bohaterów obejmowała przede wszystkim kobiety (najczęściej dojrzewające panienki przeżywające inicjację w miłość, w ciało, w życie społeczne, kobiety dojrzałe „po przejściach” lub w ich trakcie), mężczyźni toksyczni, dzieci, zwierzęta. Cechy stylistyczne, podkreślane w utworach kobiecych, to przewaga zdań złożonych współrzędnie nad zdaniami wielokrotnie złożonymi niewspółrzędnie, uporządkowanie zdarzeń fabularnych częściej na zasadzie asocjacji niż według porządku przyczynowo-skutkowego, metaforycz-

10 Por. P. Chmielowski, Autorki polskie w wieku XIX. Studium literacko-obyczajowe, Warszawa 1885; S. Morawski, O tak zwanej estetyce feministycznej, w: Czy jeszcze estetyka? Sztuka współczesna a tradycja estetyczna, Kraków 1994; G. Borkowska, Cudzoziemki. Studia o Polskiej prozie kobiecej, Warszawa 1996; K. Kłosińska, Ciało, pożqdanie, ubranie. O wczesnych powieściach Gabrieli Zapolskiej, Kraków 1999; E. Kraskowska, Piórem niewieścim. Z problemów prozy kobiecej dwudziestolecia międzywojennego, Poznań 1999; Krytyka feministyczna. Siostra teorii i historii literatury, pod red. G. Borkowskiej i L. Sikorskiej, Warszawa 2000. 
ność, emocjonalność, konkretność. W kreacji świata przedstawionego podkreślano fragmentaryczność, szczegółowość opisów, skupienie na szczególe i egzystencji codziennej.

Krytycy dostrzegali w „zalewie kobiecości” jedynie zagrożenia, przede wszystkim wyparcie z rynku wydawniczego literatury „lepszej” (tzn. tworzonej przez mężczyzn) przez literaturę ,gorszą (tzn. tworzoną przez kobiety), która jest bardziej popularna, bo stawiająca odbiorcy mniejsze wymagania. $\mathrm{W}$ istocie chodziło o lęk przed konkurencją, rywalizacją o wydawcę/popularność/pieniądze, koniecznością liczenia się z potrzebami czytelników, który ujawniał, że pisarze w latach 1918-1939 nadal myśleli o sobie jako twórcach literatury „wysokiej”, „,elitarnej” (pisarz jako wieszcz/autorytet/przewodnik społeczeństwa), podczas gdy o pisarkach myśleli jako twórczyniach literatury „niskiej”, „masowej” (pisarz jako dostawca produktu, na który istnieje zapotrzebowanie). Jedynym antidotum, jakie przychodziło do głowy krytykom literatury kobiecej, było cofnięcie skutków emancypacji, co w języku epoki brzmiało następująco: my mężczyźni musimy otoczyć kobiety większą troską niż dotąd, dzięki czemu znów poczują się „prawdziwymi” kobietami i chętnie zrezygnują z uczestnictwa w życiu publicznym i literackim, by zająć się domem i miłością.

Jak wynika z danych, które zawierają kolejne tomy „Rocznika Literackiego" z lat 30. twórczość poetycka kobiet w dwudziestoleciu międzywojennym stanowiła ok. 10\% całej produkcji lirycznej. Mimo, że był to udział skromny, był zarazem większy niż w epoce poprzedniej. Dla młodopolskiej wyobraźni charakterystyczny był zespół tematów i motywów o charakterze mitycznym, czerpanym z historii literatury i kultury Zachodu, uprzywilejowanie form trudnych, np. sonetu, obecność wielość systemów metrycznych. W tak zakreślonej przestrzeni poetyckiej kobiety nie poruszały się swobodnie, dlatego - choć oczywiście sprawdzały swoje siły we wszystkich nurtach i tematach - najbardziej charakterystyczną cechą ich twórczości młodopolskiej była nastrojowość oraz tematyka patriotyczna, religijna i erotyczna. Początek niepodległości to początek nowego okresu w liryce polskiej, który charakteryzował się ostrym sprzeciwem wobec poetyki bezpośrednich poprzedników. Miało to decydujący wpływ na postrzeganie poezji kobiecej $\mathrm{w}$ dwudziestoleciu międzywojennym, ponieważ przeważająca liczba poetek aktywnych w tym czasie sięgała do modelu modernistycznego, skodyfikowanego, łatwo rozpoznawalnego, już w latach przedwojennych zdradzającego oznaki wyczerpania, a po 1918 r. uważanego za anachroniczny. 
Drugim modelem poezjowania, do którego sięgały poetki międzywojenne, był model wypracowany przez grupę poetycką Skamander. Najwybitniejsze poetki dwudziestolecia międzywojennego - Maria Pawlikowska-Jasnorzewska, Kazimiera Iłłakowiczówna i Zuzanna Ginczanka - pozostały w kręgu poetyckiego oddziaływania Skafandra. Skamandryci łączyli elementy tradycji romantycznej i modernistycznej, tendencje ludyczne, nastrój radości, poetykę codzienności, elementy języka potocznego; propagowali wzorzec poety - uczestnika życia codziennego lub obserwatora wydarzeń opisywanych w wierszach. Do najbardziej rozpoznawalnych cech poetyki skamandryckiej należały: wiersz toniczny, melodyjność, skłonność do anegdoty, tendencje do zamykania utworu pointa, co było sprzeczne z propozycjami awangardowymi: wierszem wolnym, uznaniem metafory za podstawowy środek poetycki, układami rozkwitającymi, wstydliwością uczuć. Nic dziwnego, że poetkom bliżej było do modelu skamandryckiego niż awangardowego, ponieważ awangarda nie tylko zakładała zbyt wysoki stopień świadomości formalnej, nieosiaggalnej dla większości kobiet piszących tego okresu, lecz także zakładała zdystansowany, intelektualny stosunek do języka i rzeczywistości. Mimo że istniały poetki, jak np. Gustawa Jarecka, Krzemieniecka Lucyna czy Nina Rydzewska, które debiutowały w kręgu Kwadrygi lub Zofia Kossak-Szczucka czy Janina Brzostowska, które związały się $\mathrm{z}$ grupą poetycką Czartak, poetyki tych grup stanowiły w istocie kontynuację zmodyfikowanego modelu skamandryckiego wzbogaconego jednakże o elementy katastrofizmu i lewicowej wrażliwości na krzywdę społeczną.

Podobnie jak w poezji, tak też w dramacie kobiety stanowiły ok. $10 \%$ twórców, jednakże wpływ dramatopisarek na oblicze międzywojennego teatru był znacznie większy niż poetek na oblicze międzywojennej liryki. Sztuki pisane przez kobiety na potrzeby teatru można podzielić na trzy podstawowe grupy, z których pierwsza obejmuje utwory podejmujące szeroko rozumianą problematykę społeczną, druga - utwory skoncentrowane na kobiecie i miłości, trzecia - utwory historyczne. Dramatów społecznych i historycznych powstało zdecydowanie mniej, jeśli porównać ich ilość z ilością dramatów „kobiecych”, jednakże należały one do najlepszych realizacji tych gatunków, jakie powstały w międzywojniu. Wyostrzenie problematyki społecznej w dramacie lat 1918-1939 nastapiło wskutek nagłej dezaktualizacji problematyki patriotycznej (istotnej dla dramaturgii epoki poprzedniej) w momencie odzyskania niepodległości. Narzędzi używanych i w Młodej Polsce, i w międzywojniu do opracowania tematów społecznych dostarczał przede wszystkim ekspre- 
sjonizm, kojarzony powszechnie ze sztukami Emila Zegadłowicza czy Jerzego Hulewicza. Mimo tych skojarzeń, do najwybitniejszych osiągnięć międzywojennego dramatu ekspresjonistycznego należały - obok utworów Karola Huberta Rostworowskiego - teksty Felicji Kruszewskiej oraz Ewy Szelburg-Zarembiny. Utwory o radykalnej wymowie społecznej pisała również działaczka socjalistyczna Zofia Wojnarowska. Z kolei Halina Dąbrowolska przy opracowaniu motywu niepokojów egzystencjalnych korzystała z rozwiązań Jerzego Szaniawskiego. Dramat historyczny reprezentowały Amelia Hertzówna, Maria Dąbrowska, Zofia Kossak-Szczucka, Stanisława Przybyszewska.

Międzywojenne autorki sztuk teatralnych wyspecjalizowały się w tematyce obyczajowej i niemal każda z nich stworzyła własną odmianę dramatu obyczajowego, a przede wszystkim Maria Pawlikowska-Jasnorzewska, Maria Morozowicz-Szczepkowska, Maria Kuncewiczowa i Zofia Nałkowska. Maria Pawlikowska-Jasnorzewska koncentrowała się na psychologii kobiety, która szuka odpowiedniego dla siebie mężczyzny i wybiera rozwiązania niekonwencjonalne, np. poszukuje kochanka idealnego, rezygnuje z macierzyństwa lub decyduje się na dziecko z partnerem innym niż mąż. Maria Morozowicz-Szczepkiwska proponowała, by kobiety przyjęły męską, hedonistyczną postawę w sprawach miłości, ponieważ tylko w ten sposób mogą uzyskać autonomię i stać się równorzędnymi partnerkami mężczyzn. Z kolei Maria Kuncewiczowa konfrontowała dwa modele miłości, romantyczny i pragmatyczny, ukazując triumf tej ostatniej. Kobiecą optykę zachowała, podobnie jak w całej swojej twórczości, także Zofia Nałkowska. Odmianę melodramatyczną reprezentowały Pola Gojawiczyńska, Marcelina Grabowska, Aniela Kallas, Janina Morawska.

Opozycja wobec dziedzictwa modernistycznego, widoczna najwyraźniej w liryce lat 1918-1939, ujawniła się również w powieści, szczególnie na przełomie lat 20. i 30., kiedy wykrystalizowały się ostatecznie trzy najważniejsze nurty: realistyczny, psychologiczny i groteskowy. Kobiety pisarki najliczniej uczestniczyły w dwu pierwszych. Do nurtu realistycznego zaliczyć trzeba dwie grupy utworów, z których pierwsza obejmuje cykle powieściowe - odmianę gatunkową niezwykle popularną w literaturze europejskiej początku XX w., oraz utwory populistyczne. Do autorek zainspirowanych cyklami Marcela Prousta, Johna Galsworthy'ego, Sigrid Undset, Georgesa Duhamela, Rogera Martina du Garda, Julesa Romainsa, a współwystępujących z rodzimymi twórcami cykli, np. Andrzejem Strugiem, Juliuszem Kadenem-Bandrowskim, Jerzym Braunem, zaliczają się Maria Dąbrowska, Herminia Naglerowa, Zofia Kossak-Szczucka, Irena 
Krzywicka, Ewa Szelburg-Zarembina, Pola Gojawiczyńska, Wacława Potemkowska i in. Owe powieści rodzinne umieszczały jednostkę zawsze na tle najbliższego otoczenia, środowiska, warstwy społecznej, narodu i opowiadały historię co najmniej dwóch pokoleń, przyjmowały więc perspektywę epicką, historyczną, z oddalenia, pozwalającą zachować dystans do przeszłości i teraźniejszości. Niewątpliwie przełomowe znaczenie dla powieści międzywojennej miała publikacja Nocy $i$ dni Marii Dąbrowskiej, ponieważ wyzwoliły prozę polską z wpływów modelu Stefana Żeromskiego, Wacława Berenta i Juliusza Kadena-Bandrowskiego, które utrzymywały się do końca lat 20.

Do grupy utworów populistycznych zaliczały się te, które powstawały w kręgu wpływów zespołu „Przedmieście” lub nawiązywały do założeń programowych tej grupy. Cechą wspólną utworów populistycznych było obrazowanie życia środowisk i warstw funkcjonujących na szeroko pojętych ,peryferiach” społeczeństwa: robotników fabrycznych, biedoty wiejskiej, bezrobotnych. Tendencje faktograficzne wiązały się tu z dążeniami do autentyzmu obrazu, stąd częste sięganie przez populistów do narzędzi wypracowanych przez realizm, naturalizm, powieść środowiskową i reportaż - jeden z najmłodszych gatunków prozatorskich XX w., a także przyjmowanie perspektywy bohaterów przez autora. Utwory kobiece stanowiły zdecydowaną większość w nurcie populistycznym, a do najwybitniejszych należą teksty Kazimiery Alberti, Heleny Boguszewskiej i Jerzego Kornackiego, Janiny Brzostowskiej, Marceliny Grabowskiej, Wandy Melcer. Kobiety o sympatiach lewicowych, socjalistycznych i komunistycznych, dawały świadectwo emancypacyjnym dążeniom proletariatu, jak np. Gustawa Jarecka, Halina Krahelska, Wanda Wasilewska. Z kolei o lewicowej świadomości inteligentów-społeczników, rozczarowanych fałszywą filantropią warstw rządzących, pisały Halina Górska oraz Gustawa Jarecka.

Równie liczny udział autorek odnotowano w nurcie powieści psychologicznej, ze względu na charakterystyczną dla tej konwencji koncentrację na fenomenach życia wewnętrznego bohaterów, uważanego tradycyjnie za domenę kobiet i literatury kobiecej. Marzenia senne, rytm pamięci, mechanizm pożądania, powstawanie plotki, instynkt śmierci, chaos uczuć macierzyńskich zajmowały największych prozaików dwudziestolecia, m.in. Helenę Boguszewską, Tadeusza Brezę, Michała Choromańskiego, Anielę Gruszecką, Jarosława Iwaszkiewicza, Marię Kuncewiczową, Zofię Nałkowską, Adolfa Rudnickiego, Elżbiety Szemplińskiej. Zrywali oni z chronologicznym układem zdarzeń, sięgali po retrospekcję jako podsta- 
wowe ujęcie powieściowe oraz z tradycją kreowania spójnych „,charakterów", eksplorowali podświadomość i korzystali z odkryć psychoanalizy, co ściągało na nich gromy krytyków literatury reprezentujących różne orientacje ideowe i artystyczne.

Kobiety tworzyły także inne odmiany powieści, będące dotąd domeną mężczyzn lub stanowiące wytwór kultury masowej XX w. Pierwsze powieści radiowe napisały Helena Boguszewska i Maria Kuncewiczowa. Powieści historyczne i biograficzne tworzyły m.in. Anna Ludwika Czerny, Zofia Kossak-Szczucka i Hanna Malewska. Licznie wystapiły autorki literatury podróżniczej, wskutek rozpowszechnienia się zwyczaju samotnego podróżowania kobiet, które zaczęły w pierwszych dekadach XX w. wędrować równie często i równie daleko, jak mężczyźni. Utwory podróżnicze miały na swoim koncie np. Karolina Beylin, Alina Centkiewicz, Zofia Kossak-Szczucka, Wanda Kragen, Maria Kuncewiczowa, Hanna Mortkowicz, Zofia Nałkowska, Stefania Zahorska. Na pograniczu literatury pięknej i dokumentu znajdował się także reportaż, gatunek młody i niemal od początku swojego istnienia opanowany przez kobiety, które sytuowały się między zideologizowanym reportażem pisarzy lewicowych a reportażem politycznym, reprezentowanym przez Aleksandra Jantę-Połczyńskiego, Ksawerego Pruszyńskiego czy Melhiora Wańkowicza. Mężczyźni analizując bolączki społeczne, traktowali je inaczej niż kobiety - oni tropili mechanizmy władzy i absurdy ustroju, one ukazywały ludzką twarz kryzysu i krzywdę indywidualną. Życie codzienne w środowiskach marginesu i na „obrzeżach” społeczeństwa - życie mieszkańców enklaw żydowskich, szpitali, klasztorów, noclegowni dla bezdomnych, ochronek dla dzieci, aresztów, więzień, prostytutek, przestępców, pracowników wymiaru sprawiedliwości, chłopów i robotników, przyciagały uwagę Niny Berg, Heleny Boguszewskiej, Haliny Dąbrowolskiej, Haliny Górskiej, Marii Grossek-Koryckiej, Ireny Krzywickiej, Marii Kuncewiczowej, Wandy Melcer, Marii Milkiewiczowej, Mirosławy Parzyńskiej, Elżbiety Szemplińskej, Wandy Wasilewskiej, Ewy Szelburg-Zarembiny, Stefanii Zahorskiej.

\section{Próba podsumowania}

W latach 1918-1939 kobiety masowo weszły do literatury. Znalazły dla siebie miejsce na terenach tradycyjnie uważanych za ich domeny, czyli w literaturze dla dzieci i młodzieży, w dziale przekładów oraz w czasopi- 
smach kobiecych, ale też na terenach tradycyjnie uważanych za domeny męskie, czyli w liryce i dramacie. Najliczniejsza reprezentacja piór kobiecych pojawiła się jednak w prozie. Powieści społeczne i psychologiczne, rozwojowe i pensjonarskie, radiowe i popularne, romanse i melodramaty, opowiadania i nowele o dzieciństwie i o zwierzętach, felietony i recenzje, reportaże społeczne i podróżnicze - na wszystkich tych odmianach gatunkowych autorki odcisnęły piętno określane przez krytyków literackich tego czasu mianem „kobiecości”. Najwyraźniej dostrzegali je krytycy w powieściach społecznych i psychologicznych, w których autorki wykorzystywały własne doświadczenia, obserwacje i refleksje, dzięki czemu odsłaniały inny obraz rzeczywistości społecznej niż ten, jaki konstruowali w swoich tekstach mężczyźni. Pisarki penetrowały te środowiska i rejony rzeczywiste i metaforyczne, które do tej pory były postrzegane jako obce, gorsze, marginalne. Bohaterowie ich tekstów to mieszkańcy/rejony peryferii społeczeństwa/psychiki - prostytutki, bezrobotni, bezdomni, dzieci zaniedbane i niepełnosprawne; groźne siły podświadomości; stabuizowane czynności cielesne. Spojrzenie kobiet autorek to spojrzenie z zewnątrz/z peryferii/z dołu, odzierające mieszkańców Centrum - elitę polityczną, finansową i intelektualną, mieszkańców Warszawy, Miasta, Nowoczesnych Domów, Matki Polki i ich apologetów - z fałszywej szlachetności i samozadowolenia.

Szczególnie dużo uwagi poświęciły polskie pisarki międzywojenne, zarówno te, które tworzyły literaturę wysokoartystyczną, jak i te, które dostarczały literatury popularnej, opisowi sytuacji kobiety w kulturze patriarchalnej. W ich ujęciu Miłość, Dom, Rodzina, Mężczyzna, czyli obszary tradycyjnie przypisywane przez społeczeństwo i kulturę przyjmującą perspektywę męską, okazały się nie źródłem osobistego szczęścia, radości i spełnienia, lecz źródłem niesamodzielności emocjonalnej, intelektualnej i ekonomicznej kobiety. Mężczyzna w większości utworów kobiecych tego okresu to umiłowany nieprzyjaciel, który wodzi na pokuszenie partnerkę niewinną duchowo i cieleśnie, porzuca „skalaną”, zdradza, nalega na aborcję, nie wywiązuje się z obowiązków opiekuna, męża, ojca, głowy rodziny - spoczywających na nim na mocy tradycji. Namiętność erotyczna często postrzegana była jako wewnętrzny wróg, a własne ciało jako zdrajca, gdyż uzależniały kobietę od mężczyzny, mogły tyleż zapewnić kobiecie sukces (zdobycie mężczyzny) w świecie męskim, co stać się przyczyną jej klęski (zdrada, porzucenie). Macierzyństwo w takiej sytuacji stawało się problematyczne - bohaterki utworów kobiecych albo w ogóle nie posiadają kontroli nad własnym ciałem, albo świadome za- 
wodności dostępnych metod lękają się nieplanowanej ciąży. Najczęściej widzimy je w takich sytuacjach życiowych, które nie sprzyjały posiadaniu dzieci, np. wtedy, gdy weszły w związek z mężczyzną żonatym lub partnerem, który nie był zainteresowany jego legalizacją. Czytelniczki towarzyszyły im wówczas w podejmowaniu decyzji o samotnym macierzyństwie lub aborcji, przeżywając wraz z nimi niepokój o ich życie i zdrowie, trudności w znalezieniu nowego mieszkania, pracy, partnera.

Ciało to szczególny temat literatury kobiecej w okresie międzywojennym, ponieważ przekroczyła ona tabu, jakim obłożone były kobiece procesy fizjologiczne w kulturze i literaturze epok poprzednich. Pisarki tego czasu po raz pierwszy otwarcie zaczęły pisać o menstruacji, ciąży, porodzie, karmieniu piersia, potrzebach i doznaniach erotycznych, terrorze piękności i młodości, dramatach aborcji, choroby i starzenia się. Raz zachwycały się biologicznością, naturalnością swojej egzystencji, innym razem nienawidziły siebie za zwierzęcość, która wydawała je na łup zmysłów, płodów pasożytujących w ich wnętrzach, noworodków karmionych jak „małe” przez samicę. Raz czerpały przyjemność ze świadomości własnej urody przyciągającej oczy mężczyzn, innym razem znów nienawidziły swojego ciała za zmarszczki, siwe włosy, niedołężność, które czyniły je istotami ,niewidzialnymi”.

Literatura kobieca po I wojnie światowej stanowiła więc nie tylko zapis mechanizmów działania kultury androcentrycznej, lecz także świadectwo lęków kobiecych przez tę kulturę generowanych. Znaczący wydaje się wybór przez większość pisarek metody realistycznej, zakładającej obiektywizm relacji, utożsamiającej autora z narratorem, ustanawiającej subtelne porozumienie między odbiorcą i nadawcą, ponieważ dzięki niej kobiety jako pisarki i jako czytelniczki porozumiewały się ponad głowami niewtajemniczonych w sprawy kobiece; opowiadały sobie historie o tym, co usłyszały, zobaczyły lub przeżyły, ku przestrodze, wsparciu lub pocieszeniu. Zawsze jednak określały się wobec mężczyzny, ponieważ nadal nie wyobrażały sobie siebie jako osoby niezależnej emocjonalnie i finansowo, dla której związek z mężczyzną, małżeństwo i macierzyństwo mogłyby być jednym z wielu równoważnych modeli życia. Interesujący może więc być fakt, że propozycje „dokończenia” emancypacji obyczajowej, czyli uznania przez kobietę, że najważniejszym związkiem miłosnym w życiu kobiety jest związek ze sobą samą, pojawiły się nie w głównym, wysokoartystycznym nurcie literatury kobiecej, lecz na jego obrzeżach - w komediach 
obyczajowych Marii Morozowicz-Szczepkowskiej oraz powieściopisarstwie i publicystyce Ireny Krzywickiej ${ }^{11}$.

\section{Summary}

The author attempts to present the most significant results of the research on literary and para-literary activity of women in the nineteen-twenties and -thirties, from the gender perspective. The subject of the study is provided by dictionary entries discussing the biographies and works of Polish feminine writers in the first half of the twentieth century, as well as the reception of so-called „women's literature”, primarily in terms of reviews published in the literary, social and cultural press of that period. The main point of interest is the method of constructing intimate and artistic biographies of women, the manner applied by literary critics to the discussion of feminine art, the issue as to whether women's literature created in 1918-1939 was aware of its manifold conditioning and whether this literature diagnosed the social situation of women in the first decades of the twentieth century.

${ }^{11}$ S. Walczewska, Damy, rycerze feministki. Kobiecy dyskurs emancypacyjny w Polsce, Kraków 1999; A. Górnicka-Boratyńska, Stańmy się sobq. Cztery projekty emancypacji (1863-1939), Izabelin 2001. 